\title{
A análise do uso da terra no entorno do trecho oeste do Rodoanel Mario Covas na cidade de São Paulo por meio de técnicas de Sensoriamento Remoto $^{1}$
}

\section{Larissa Lucciane Volpe ${ }^{2}$ Magda Adelaide Lombardo ${ }^{3}$}

Resumo: A construção de uma rodovia pode interferir na dinâmica urbana na medida em que transforma o uso da terra nas suas proximidades. $O$ trecho oeste do eixo viário Rodoanel Mario Covas na RMSP, nos bairros Perus e Jaraguá na cidade de São Paulo, foi estudado por meio da caracterização do uso da terra em seu entorno. Para tanto foi realizado um levantamento de informações com trabalhos de campo e foram utilizadas técnicas de sensoriamento remoto para o mapeamento. Em um Sistema de Informações Geográficas foram feitos dois tipos de classificação digital, a analógica e a automática, em uma imagem de alta resolução (IKONOS do ano de 2002) e em fotografias aéreas do ano de 1994. Pela análise comparativa observouse que a classificação analógica foi a mais adequada para a análise temporal, pois permitiu a elaboração de mapas temáticos e melhor visualização dos resultados. Com a análise quantitativa das classes geradas e trabalhadas, concluiu-se que, do ano de 1994 ao ano de 2002, a área verde densa aumentou, a área de gramínea e árvores esparsas diminuiu, a área de solo exposto diminuiu e a área construída aumentou. Os resultados foram organizados em mapas temáticos ilustrando a análise temporal realizada.

Palavras-chaves: Uso da Terra; Eixo Viário, Rodoanel Mario Covas - RMSP - Sensoriamento Remoto

\begin{abstract}
The construction of a highway may interfere with urban dynamics when transform the land use around it. The western section of the road axles Mario Covas in the Metropolitan area of Sao Paulo in the neighborhoods of Perus and Jaragua in São Paulo city was studied with the characterization of the use and occupation of land around it. We did a survey of information with field work and were used remote sensing techniques for mapping. In a GIS have been made both types of digital classification, an analog and a automatic, a high resolution (IKONOS of 2002) and aerial photographs of 1994. For the comparative analysis showed that the classification analog was the most suitable for temporal analysis, because it allowed the preparation of thematic maps and better visualization of the results. With the quantitative analysis of the generate classes and worked, it was concluded, it was concluded that, in the year 1994 to 2002, the dense green area increased, the área of grass and scattered trees fell, the area of bare ground decreased, the built área increased. The results were organized in thematic maps showed the temporal analysis.
\end{abstract}

Key-words: Land Use - Roads Axles - Mario Covas Expressway - MRSP - Remote Sensing

\footnotetext{
1 Artigo elaborado a partir da Dissertação de Mestrado: VOLPE, L. L. Análise da paisagem no entorno dos eixos viários: o exemplo do Rodoanel Mario Covas na RMSP. Dissertação (Mestrado em Geografia Física) - Faculdade de Filosofia, Letras e Ciências Humanas, Universidade de São Paulo, São Paulo, 2009.

2 larissa.volpe@yahoo.com.br Universidade de São Paulo. CAPES e CNPq. Artigo elaborado em janeiro de 2010.

3 mlombardo@usp.br Universidade de São Paulo.
} 


\section{INTRODUÇÃO}

Analisando parte do histórico da metrópole de São Paulo e sua região (Região Metropolitana de São Paulo - RMSP) (Figura 1), pode-se dizer que a implantação de eixos viários terrestres, desde as trilhas para a Baixada Santista na Serra do Mar no século XVIII até a implantação dos eixos ferroviários e, posteriormente, rodoviários, foi fundamental para o crescimento econômico e para a expansão da área urbana na cidade e sua região, pois foram desencadeadas mudanças significativas na dinâmica urbana.

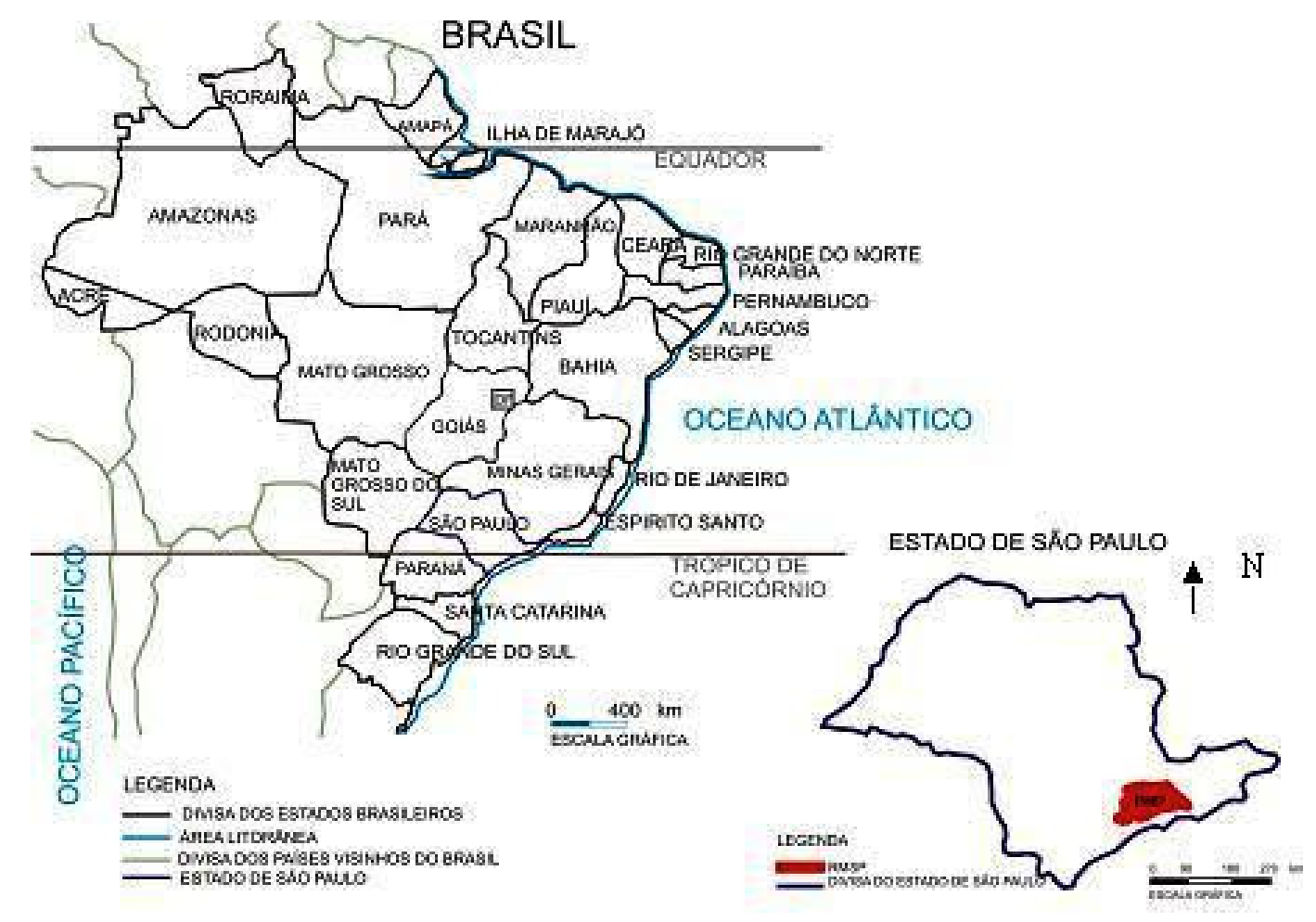

Figura 1: Localização da RMSP no estado e no Brasil

Fonte: IBGE (BRASIL, 2004). Org. Larissa L. Volpe, 2007

O objetivo da pesquisa foi traçado de acordo com a problemática levantada sobre as transformações que a implantação de um eixo viário pode trazer para seu entorno. A partir daí, a rodovia escolhida para ser estudada foi o trecho oeste do Rodoanel Mario Covas na RMSP por se tratar de uma rodovia ainda com resultados recentes de sua implantação, abranger uma importante região metropolitana, por ser uma rodovia "classe zero", isto é, sem possibilidade de acesso às áreas lindeiras, e por se tratar de uma rodovia não radial, diferente dos principais eixos viários da RMSP (Figura 2). 


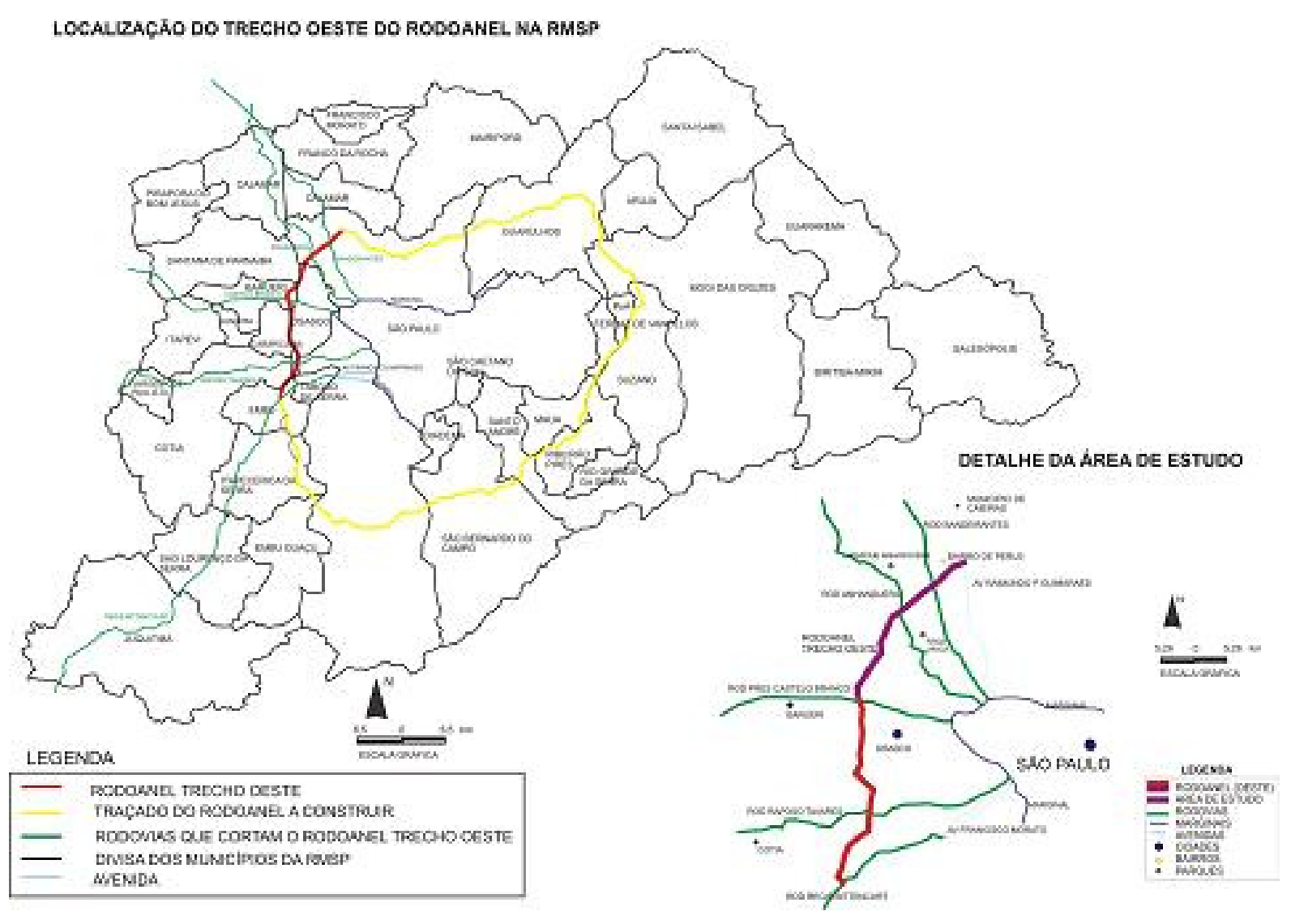

Figura 2: Localização do Rodoanel na RMSP

Fonte: Fundação Escola de Sociologia e Política de São Paulo (2004) e Departamento de Estradas e Rodagem (2004). Organizado por Larissa L. Volpe, 2009.

Foram realizados métodos de análise do uso da terra visando avaliar a transformação ocorrida na paisagem urbana do entorno do Rodoanel Mario Covas trecho oeste. A área estudada envolveu $2 \mathrm{~km}$ do entorno da rodovia nos bairros de Perus e Jaraguá na cidade de São Paulo.

\section{Análise do Entorno dos Eixos Viários: O Exemplo do Rodoanel Mario Covas}

A proximidade de rodovias é um forte atrativo para a implantação de novos empreendimentos. Em São Paulo, o aumento do fluxo de transporte voltado para indústrias, comércios e serviços unindo a capital com a região, o restante do estado e do país, associado à deficiência de transportes públicos para trabalhadores e moradores, ocasionou uma sobrecarga dos eixos viários. "Uma metrópole espraiada e dispersa significa maior tempo de deslocamento de seus habitantes, maior tráfego de veículos e maior movimento pendular entre o local de moradia e o local de trabalho". (LENCIONI, 2008, p.10). 
"A partir dos anos 50, desencadeou-se uma acelerada implantação de rodovias, começando com a Anchieta, para substituir e aumentar a capacidade da antiga Estrada Caminho do Mar, e a Presidente Dutra, para melhorar e aumentar a capacidade da Estrada Velha Rio - São Paulo. Depois, foi a Anhangüera, em substituição à Estrada Velha de Campinas. Na região de Sorocaba, o acesso recorria à rodovia Raposo Tavares. Para o Sul, segue a Régis Bittencourt. Para o norte, através da Fernão Dias. Com esses eixos viários e outros menos expressivos, abertos ao seu entorno, aconteceu a expansão radial da metrópole." (SÃO PAULO, 2004, p.44-45).

A ocupação na periferia da cidade de São Paulo e na região metropolitana é um fator relevante no aumento do tráfego nas rodovias, pois a maioria dos empregos continua na área central, o que força os trabalhadores a viajarem e dependerem vias de acesso de intensa movimentação diariamente. Segundo a empresa DERSA:

"[...] embora o assentamento populacional na periferia tenha gerado certo contingente de empregos induzidos, correspondente ao terciário tipicamente local (pequeno comércio, serviços locais, etc.), o grosso dos empregos na RMSP permaneceu nas áreas centrais consolidadas. Se os empregos ficam no centro e a população vai para a periferia é óbvio que aumentam a quantidade e a extensão dos deslocamentos residênciatrabalho, a causa mais importante das viagens. Ao se relembrar que isso está ocorrendo em uma das mais populosas cidades do mundo fica nítida a dimensão do desafio crescente, quiçá inalcançável, que se coloca para o sistema de transporte urbano (SÃO PAULO, 2005,p.3)."

O Rodoanel Mario Covas foi traçado com o objetivo de aliviar o tráfego no centro urbano e nas vias de intenso movimento da cidade de São Paulo, interconectando importantes rodovias radiais que ligam a RMSP com o interior do estado e do país. O projeto do traçado completo do Rodoanel visa circundar e distar de 20 a $40 \mathrm{~km}$ da capital, e segundo a DERSA (SÃO PAULO, 2004, p.1) "é uma rodovia "classe 0", isto é, possui alto padrão técnico e controle total de acessos". O trecho oeste do Rodoanel foi concluído em 1998, localiza-se na RMSP e interliga as rodovias Bandeirantes, Anhanguera, Castelo Branco, Raposo Tavares e Regis Bittencourt. Possui 31,6 quilômetros de extensão, faixa de interesse de 130 metros e abrange os municípios de São Paulo, Embu, Cotia, Barueri, Carapicuíba, Osasco, Santana do Parnaíba.

A área estudada envolveu a cidade de São Paulo, especificamente os bairros de Perus e Jaraguá, totalizando uma área de $39,75 \mathrm{~km} 2$. A área envolveu também uma parte da Vila Santa Fé do município de Osasco, totalizando uma área de 2,03 km2. Foi estudado o entorno de $2 \mathrm{~km}$ do trecho que segue até o início do túnel de acesso ao município de Osasco. 
De acordo com Santos (2004, p.43), uma área de estudo pode ser definida segundo limite territorial, raios de ação, corredores e unidades homogêneas. Se o planejamento visa à conservação de um território onde são comuns padrões de paisagem e atividades em extensão linear, como estradas [...] então pode-se utilizar como estratégia corredores que abrange uma faixa marginal às atividades e aos padrões de paisagem que se pretende avaliar. O Rodoanel trecho oeste é um corredor com atividades de extensão linear. De início, a área estudada abrangia aproximadamente 400 metros no entorno deste eixo viário. Segundo os autores Jorge, Pineda e Férnandez (2004) que estudam o planejamento de estradas e impactos ambientais, "considerando experiências prévias, se sugere um corredor de uns 400 metros de largura ao redor da linha entre a origem e o destino" (tradução da autora). Porém, durante os trabalhos de campo e análise das imagens aéreas, foram observadas que modificações ocorrem em linhas perpendiculares ao traçado linear do Rodoanel a mais de 400 metros. Dessa forma, optou-se por aumentar o traço perpendicular para aproximadamente $2 \mathrm{~km}$. As modificações no entorno do Rodoanel foram identificadas, caracterizadas e representadas por meio de mapas temáticos. Segundo Santos (2004, p.97):

"As formas de uso e ocupação são identificadas (tipo de uso), espacializadas (mapa de uso), caracterizadas (pela intensidade de uso e indícios de manejo) e quantificadas (percentual de área ocupada pelo tipo). As informações sobre este tema devem descrever não só a situação atual, mas as mudanças recentes e o histórico de ocupação da área de estudo."

Uma forma de espacializar e quantificar o uso da terra é por meio da coleta, manipulação e visualização dos dados. Os métodos de informações digitais, evoluídos nas últimas décadas, mostram-se cada vez mais eficazes para organizar e representar dados.

As imagens aéreas são capazes de mostrar, de maneira instantânea, porém estática, a caracterização do espaço. Cabe, portanto, ao observador extrair as informações e determinar o período de observação que necessita. Para Luchiari, Kawakubo e Morato (2005, p.46) a interpretação dos produtos de sensoriamento remoto permite efetuar inúmeros mapeamentos, dentre eles, a ocupação urbana. As técnicas de sensoriamento remoto e os Sistemas de Informações Geográficas são utilizados em muitos trabalhos visando fornecer subsídios ao planejamento de áreas urbanas. Para Ho e Lee (2000):

"O Sistema de Informações Geográficas (SIG) possui poderosas ferramentas para análise espacial de dados e administração da informação do solo [...] O Sistema de Informações Geográficas (SIG) é uma recente tecnologia extremamente usada na pesquisa de 
problemas do uso do solo. O SIG adota métodos numéricos e ferramentas de análises espaciais no delineamento do uso do solo. (Tradução da autora) ."

Um SIG é capaz de armazenar, gerenciar e manipular dados geográficos advindos de fontes como produtos cartográficos, dados numéricos e produtos de sensoriamento remoto por meio de técnicas computacionais e matemáticas, podendo assim, representar as características do uso da terra e a sua dinâmica por meio de análises em determinados intervalos de tempo (análise temporal).

\section{MATERIAIS E MÉTODOS}

Os materiais utilizados para análise do entorno do Rodoanel Mario Covas, trecho oeste, foram cartas topográficas do IBGE (Folhas Santana do Parnaíba e Guarulhos de 1984, escala 1:50000 e equidistância entre as curvas de nível de 20 metros); fotografias aéreas de 1994, escala de 1:250005; imagens de alta resolução IKONOS de 2002 com resolução de 1 metro6; documentos cedidos pela empresa DERSA (EIA, AAE); dados de domínios públicos (IBGE, SEADE) e material referente à revisão bibliográfica.

Os programas utilizados foram o ArcGis 9.2 e o Spring 4.3.3. Antes de iniciar o processo de interpretação das imagens, foi realizado o georreferenciamento de acordo com as coordenadas contidas nas cartas topográficas do IBGE (BRASIL, 1984) e referências coletadas por meio de um GPS (Global Position System) em trabalhos de campo. A análise temporal foi feita por meio de sobreposição das fotografias aéreas de 1994 (Figura 3) e da imagem aérea de alta resolução IKONOS de 2002 (Figura 4).

\footnotetext{
"A detecção de mudanças se dá pela sobreposição de imagens ou mapas de diferentes datas, nos quais ressaltam-se as diferenças que são reclassificadas para extrair as alterações significativas. Uma maneira de discriminar as mudanças ocorridas entre as imagens é obter uma classificação independente de cada imagem, registrando os resultados e localizando as células que apresentem diferenças. Outra maneira é inscrever as duas imagens no SIG e preparar uma imagem de diferença temporal." (SANTOS, 2004, p.54)
}

Para a representação do uso da terra e análise temporal foi necessária a criação de classes buscando envolver "elementos naturais e artificiais" (SANTOS, 1999).

O primeiro processo de classificação foi feito manualmente (classificação analógica), sendo realizado nas fotografias aéreas de 1994 e na imagem de alta resolução de 2002 - IKONOS, onde foi estabelecido o número de classes pelo usuário e atribuída às imagens (Figura 5). 


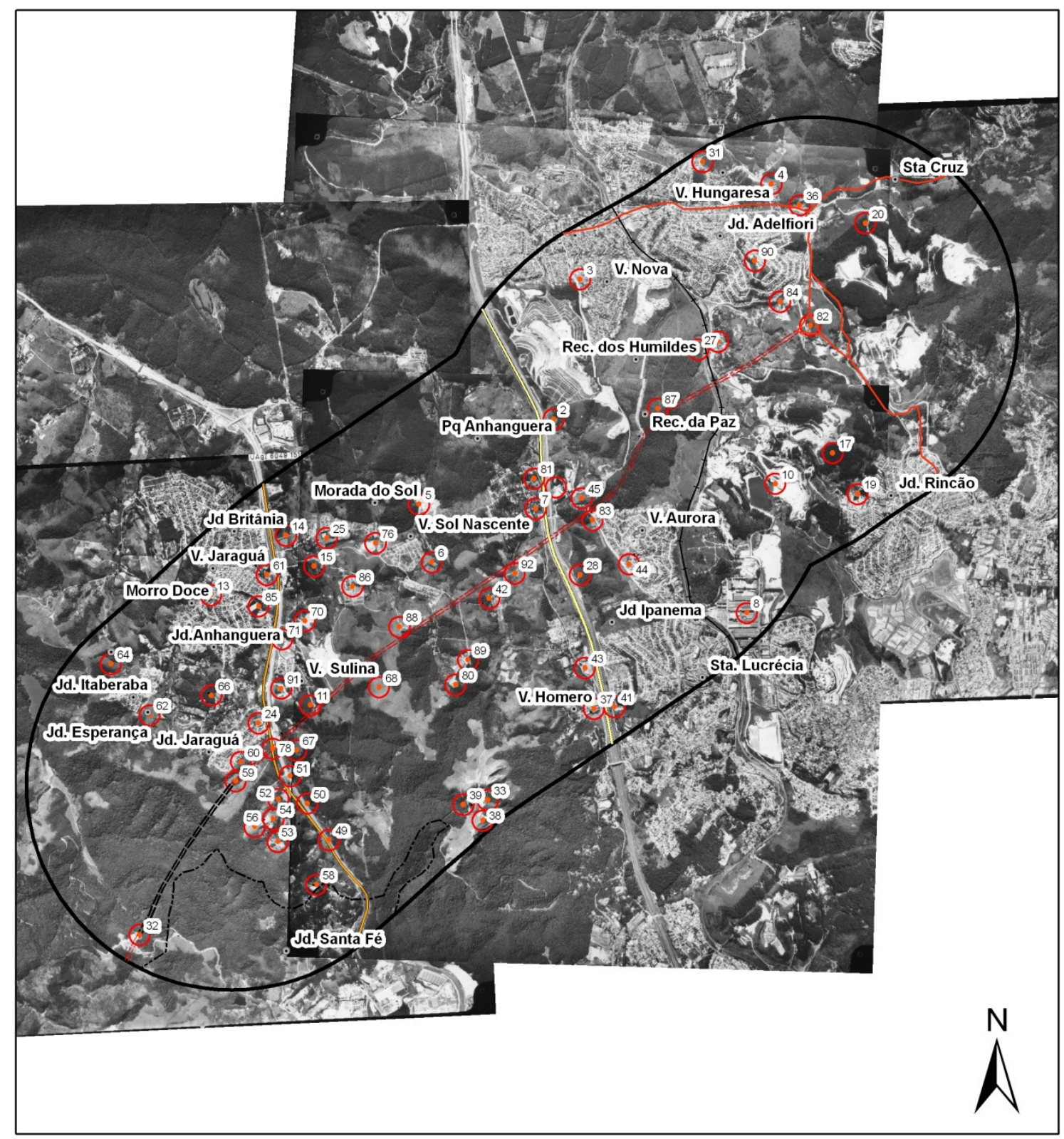

Escala Gráfica

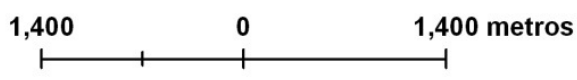

\footnotetext{
Legenda

$\square$ Área de estudo

- Local visitado com buffer de $100 \mathrm{~m}$

$====$ Traçado do Rodoanel Mario Covas

$====$ Traçado do Túnel do Rodoanel

Rodovia dos Bandeirantes

_ Rodovia Anhanguera

- Estradas

+ Ferrovia

-.--.. Divisa municipal (São Paulo e Osasco)
}

Figura 3: Fotografias aéreas (1994).

Elaborado por Larissa L. Volpe, 2009. 


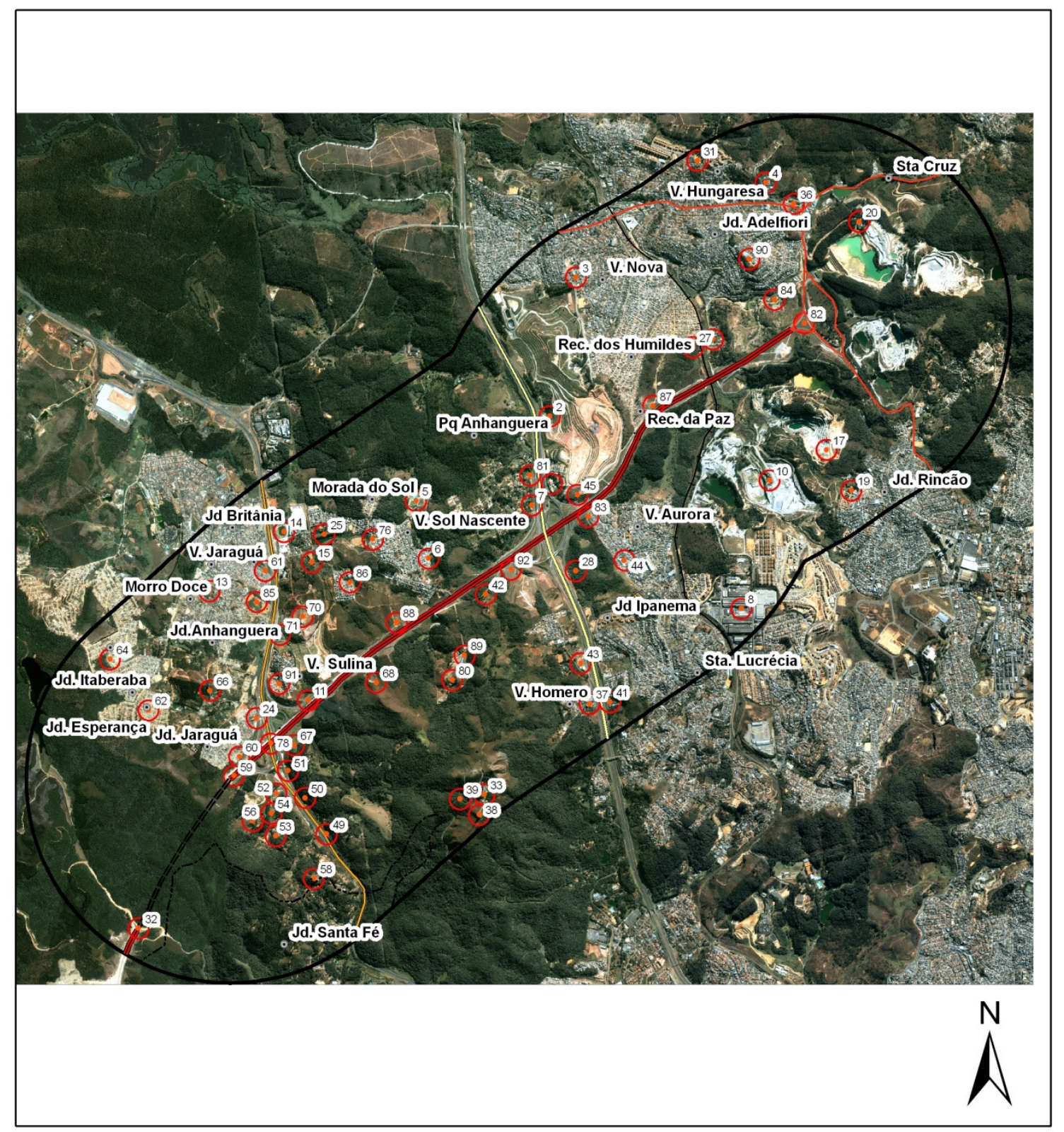

\section{Legenda}

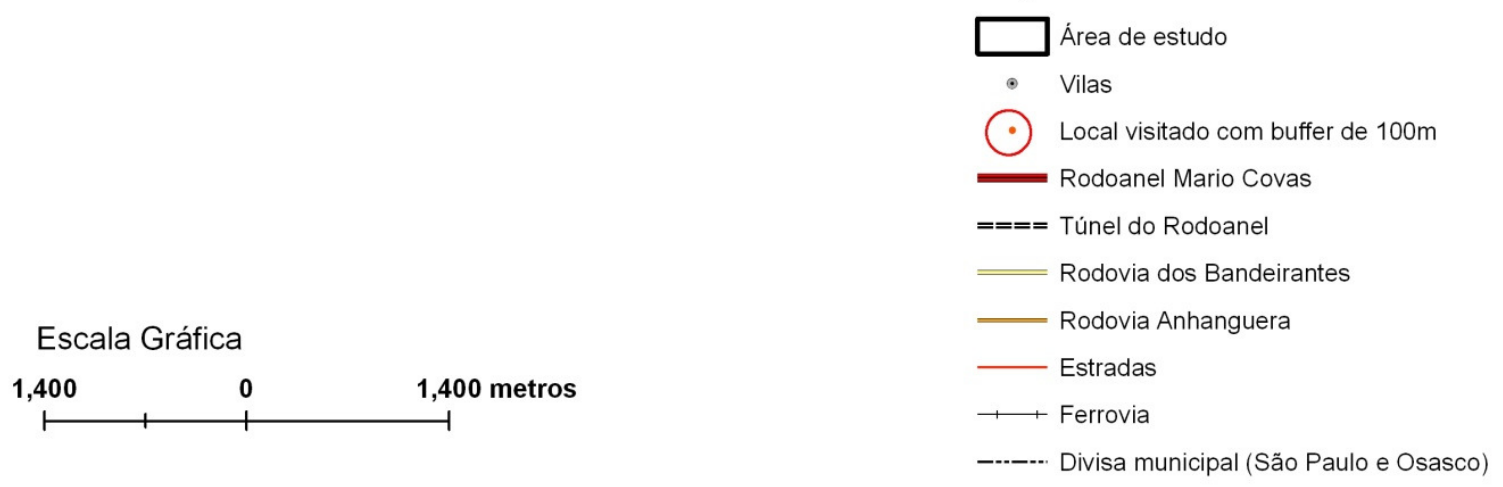

Figura 4: Imagem de alta resolução IKONOS (2002). 
Elaborado por Larissa L. Volpe, 2009.
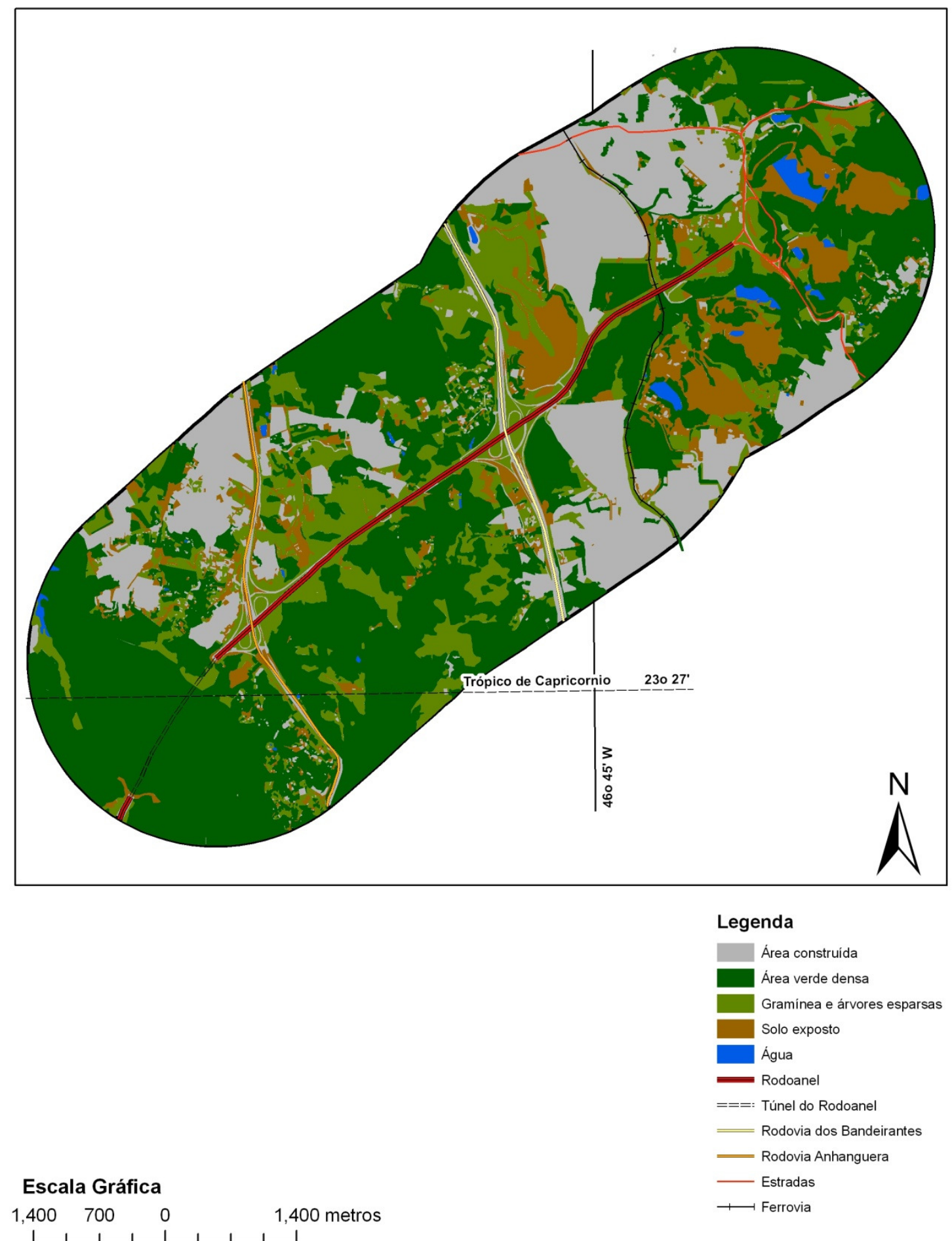

Figura 5: Classificação analógica na imagem IKONOS do ano de 2002. Elaborado por Larissa L. Volpe, 2009. 
As classes criadas foram: Área construída (vilas, casas e galpões); Área verde densa (fragmentos de mata); Gramínea e árvores esparsas (vegetação rasteira e árvores espaçadas); Solo exposto (terrenos ou ruas com solo exposto); Água (lagos e lagoas).

Na imagem IKONOS foi feita a classificação automática, onde o SIG atribuiu classes automaticamente à imagem, sem a coleta de amostras pelo usuário (não supervisionada) e com a coleta de amostras (supervisionada). As classes criadas na classificação automática sofreram algumas modificações, pois não foi possível a identificação de algumas áreas, como água, por exemplo, por serem muito distintas (ex: água de piscinas tem a cor azul clara; água de lagos tem a cor cinza escura; água de lagoas em áreas de mineração assoreadas possuem cores em tonalidade marrom). Na classificação automática foi possível estabelecer áreas como sombra, o que não foi possível estabelecer no modo analógico nas fotografias aéreas por estarem muito próximas às outras classes e não permitirem distinção na visibilidade.

As classes definidas na classificação automática foram: Área construída (vilas, casas e galpões); Área verde densa (fragmentos de mata); Área verde esparsa (vegetação rasteira e árvores espaçadas); Solo exposto (terrenos ou ruas com solo exposto); Sombra (sombra de árvores ou construções); Nenhum (nenhuma das classes acima).

Ao todo foram realizados cinco testes no programa Spring 4.3.3, sendo três classificações supervisionadas e duas classificações não supervisionadas por regiões 7.

A imagem IKONOS foi tratada com manipulação de contraste antes de iniciar o processo de segmentação e classificação. A segmentação é um processo anterior a classificação e consiste em agrupar os pixels por regiões. Segundo Instituto Nacional de Pesquisas Espaciais - INPE (2002) "Entende-se por região um conjunto de pixels contíguos, que se espalham bidirecionalmente e que apresentam uniformidade espectral".

"A classificação é o processo de extração de informação em imagens para reconhecer padrões e objetos homogêneos. O resultado final de um processo de classificação é uma imagem onde cada pixel contém a informação de uma classe, ou tema, associada ao ponto de uma cena correspondente." (TUTORIAL SPRING, 2002).

Dos testes executados, foi escolhido o que mais apresentou resultados próximos a fotointerpretação da imagem e aos trabalhos de campo (Imagem Sintética; Projeção UTM/WGS84; Classificador Bhattacharya; Treinamento Supervisionado; Limiar de aceitação de 75\%, Análise por Regiões.) (Figura 6). 
No processo de classificação foram coletadas amostras para classificação da imagem. Foram criadas sete classes pelo programa, e foram reduzidas a seis classes. O banco de dados contendo estas classes foi exportado para outro SIG (ArcGis 9.2) para a elaboração do mapa temático, sendo feita então, a legenda definitiva (Figuras 7 e 8).

No caso da classificação automática supervisionada, para se coletar áreas amostrais na imagem visando à criação de classes e da legenda é preciso que se tenha conhecimento da área, é o que Pinho (2006) chama de "sistemas baseados em conhecimento".

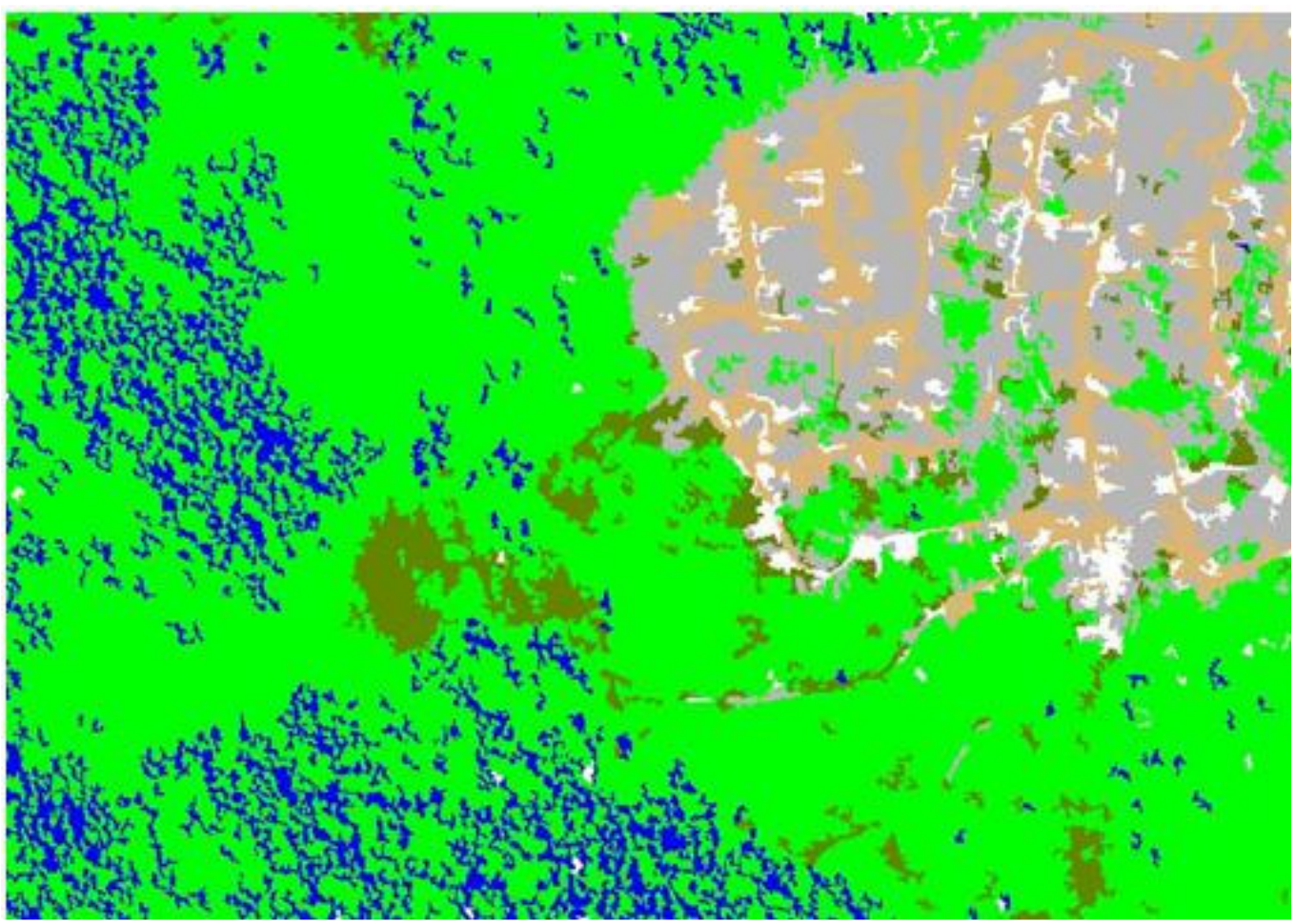

Figura 6: Exemplo de classificação automática supervisionada por regiões Bhattacharya 75\%. Elaborado por Larissa L. Volpe, 2009.

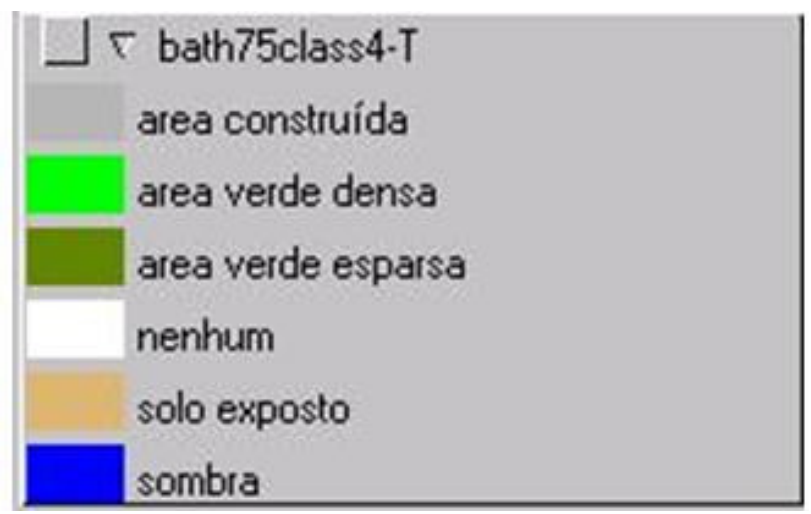

Figura 7: Classes atribuídas pela autora após a classificação automática supervisionada (Spring) Elaborado e organizado por Larissa L. Volpe, 2009 


\section{Legenda}

Área construida
Área verde densa
Graminea e árvores esparsas
Solo exposto
Sombra
$\square$ Área năo identificada

Figura 8: Elaboração da legenda após exportação de dados (ArcGis)

Elaborado e organizado por Larissa L. Volpe, 2009

"O funcionamento destes sistemas baseia-se na introdução do conhecimento do analista a respeito da cena, ou seja, é uma formalização da "visão" de um determinado indivíduo sobre uma cena específica. Assim, o resultado da classificação é um reflexo do conhecimento (informações coletadas a priori sobre a área a ser classificada) e da capacidade de compreensão do analista (fortemente influenciada por sua formação profissional e experiência) a respeito de uma determinada cena." (PINHO, 2006, p.41)

Posteriormente, as classes são avaliadas e são determinadas novas classes pré-definidas pelo usuário substituindo aquelas criadas pelo programa (Figura 9).

A realização da análise temporal foi possível por meio da classificação analógica nos anos de 1994 e 2002. Não foi realizada esta análise por meio de classificação automática, pois não foi possível realizá-las com as fotografias aéreas de 1994 pela baixa resolução desta imagem.

\section{Análise Temporal (1994 e 2002)}

O banco de dados georeferenciado da classificação analógica do ano de 1994 foi comparado ao da classificação analógica do ano de 2002, resultando nos mapas temáticos:

Área Verde Densa: presença de fragmentos de mata no ano de 1994, no ano de 2002 e as áreas existentes nas duas datas (Figura 10). Caracterizam-se normalmente por fragmentos de mata e áreas de proteção como o Parque do Pico do Jaraguá; Gramínea e Árvores Esparsas (Figura 11): presença de vegetação rasteira e árvores espaçadas no ano de 1994, no ano de 2002 e as áreas existentes nas duas datas; Solo Exposto (Figura 12): presença de solo exposto nos anos de 1994, no ano de 2002 e as áreas existentes nas duas datas. As maiores áreas de solo exposto são as cavas de mineração, seguidas de ruas não asfaltadas em vilas carentes e terrenos erodidos; Áreas Construídas: presença de construções no ano de 1994, 
no ano de 2002 e as áreas existentes nas duas datas (Figura 13). Caracterizam-se principalmente pelas vilas residenciais.
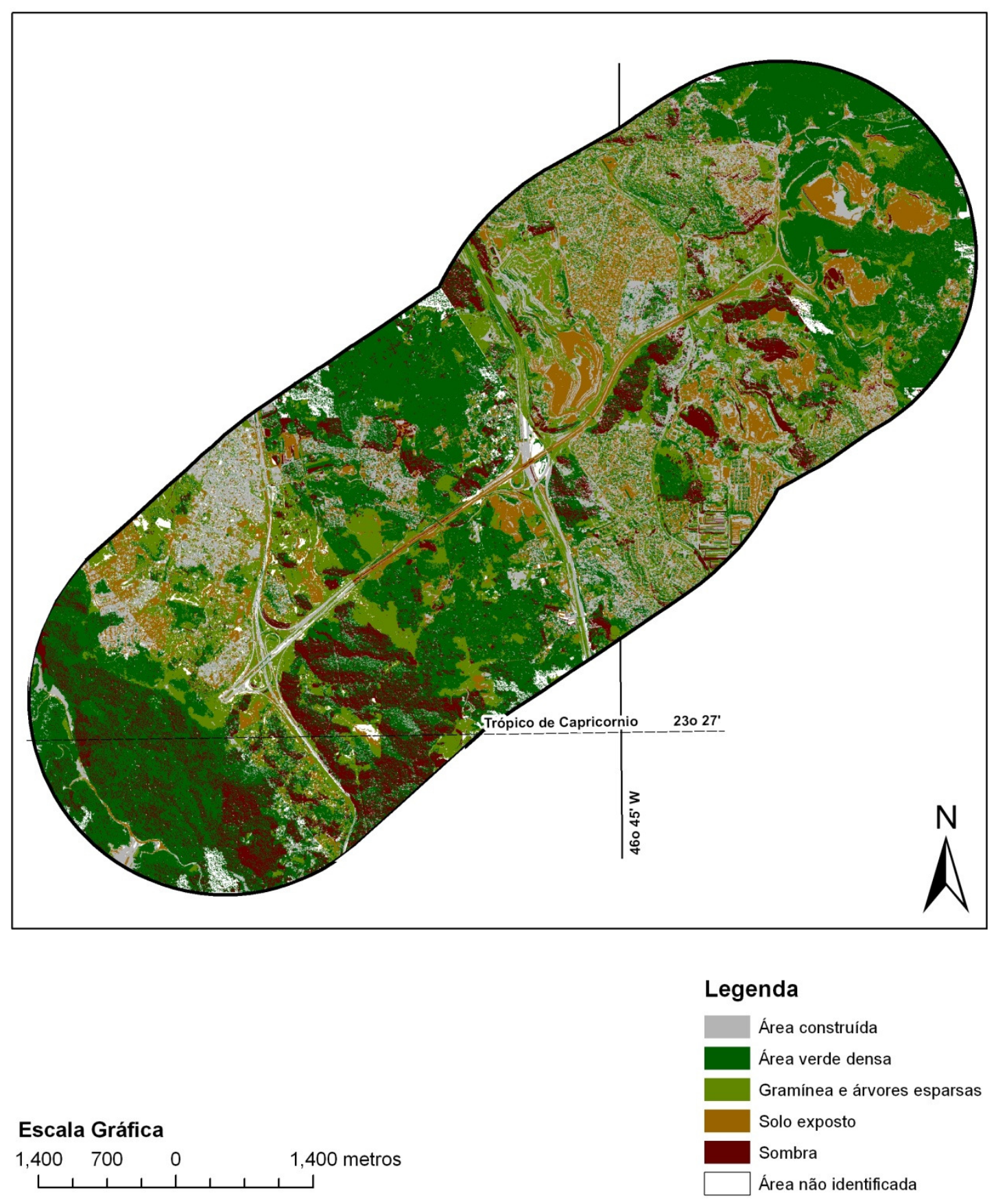

Figura 9: Classificação automática na imagem IKONOS do ano de 2002.

Elaborado por Larissa L. Volpe, 2009. 


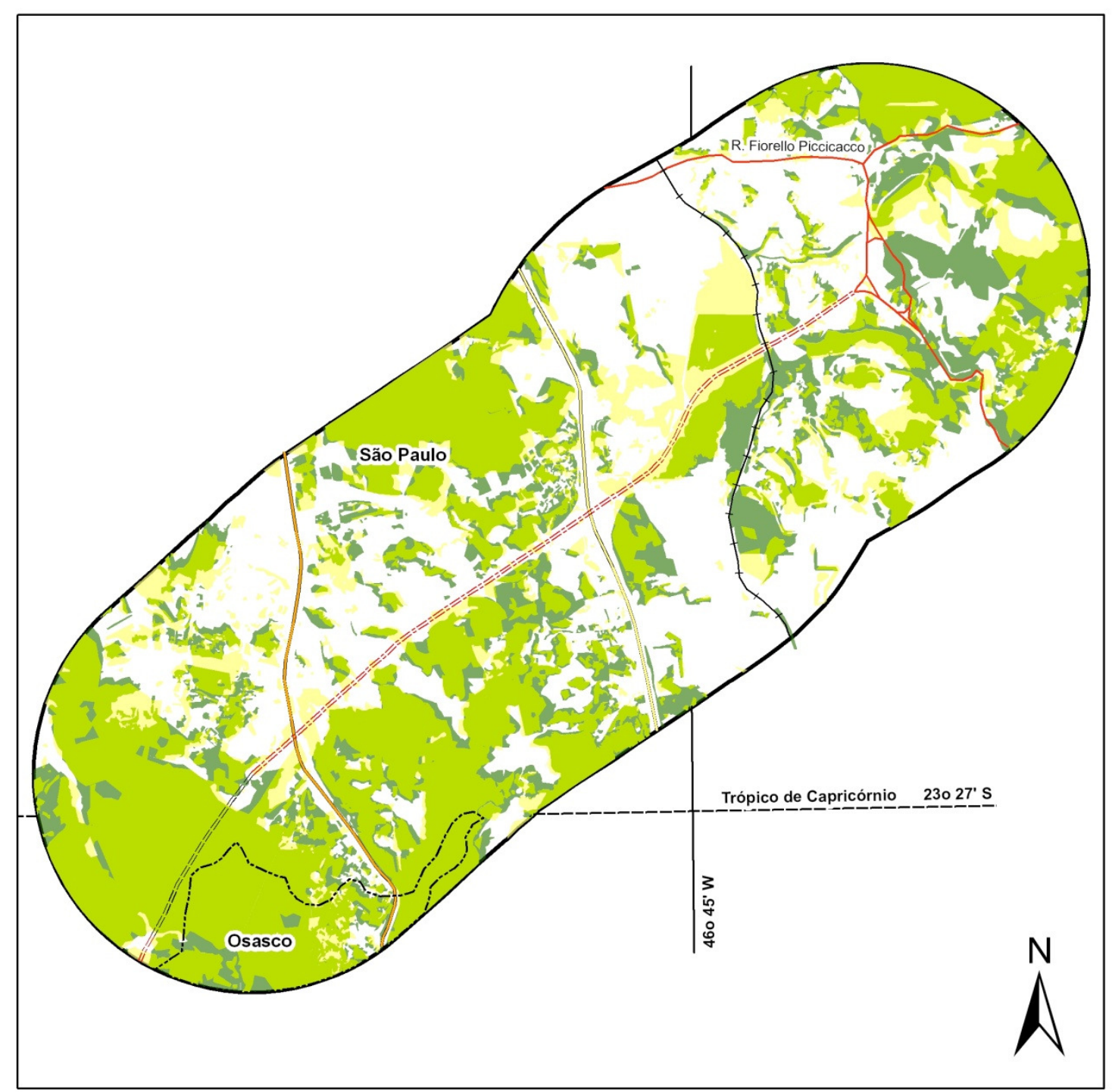

\section{Escala Gráfica}

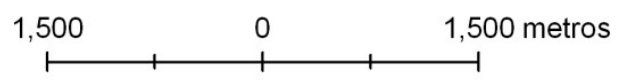

\section{Legenda}

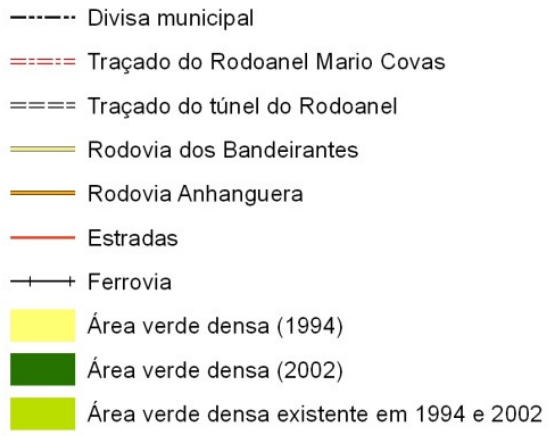

Figura 10: Presença de área verde densa em 1994 e 2002.

Elaborado por Larissa L. Volpe, 2009. 


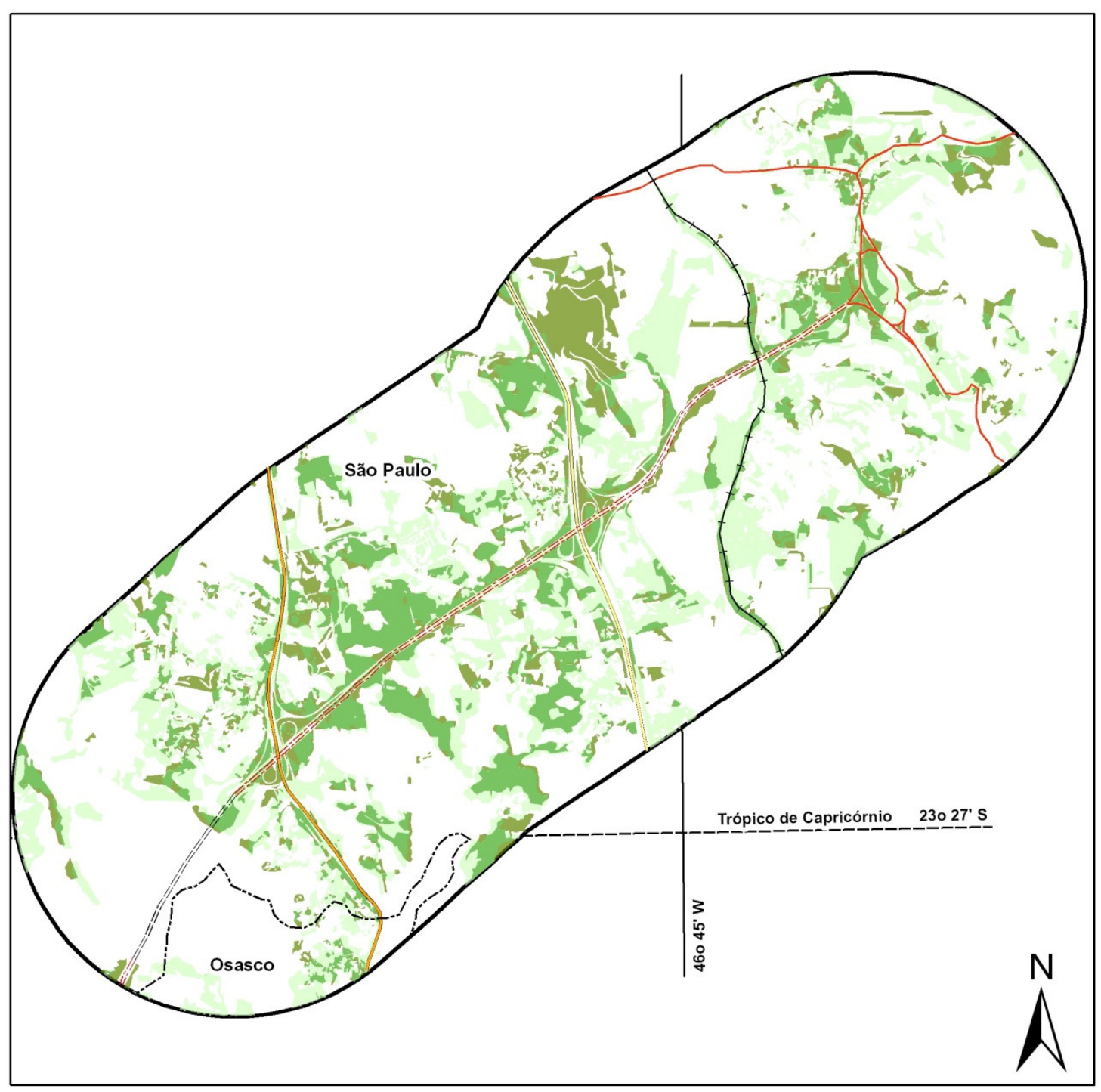

\section{Legenda}

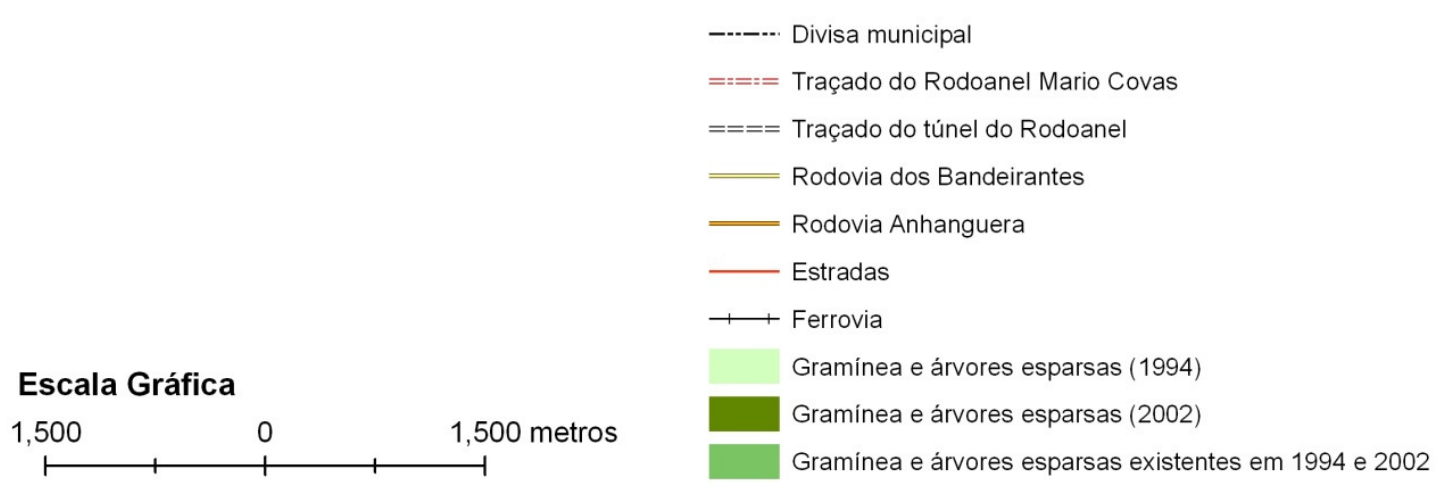

Figura 11: Presença de gramíneas e árvores esparsas em 1994 e 2002.

Elaborado por Larissa L. Volpe, 2009. 


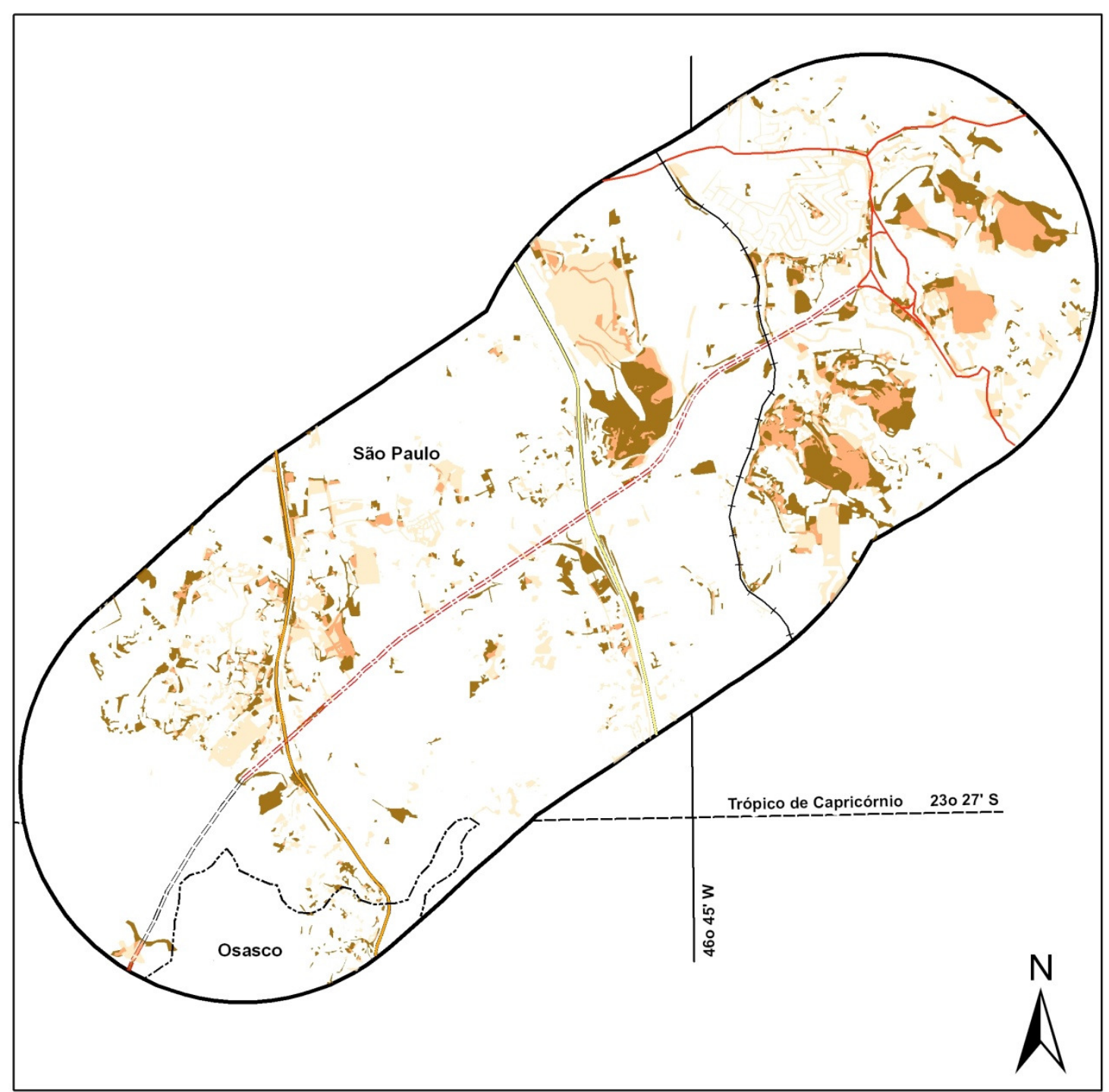

\section{Legenda}

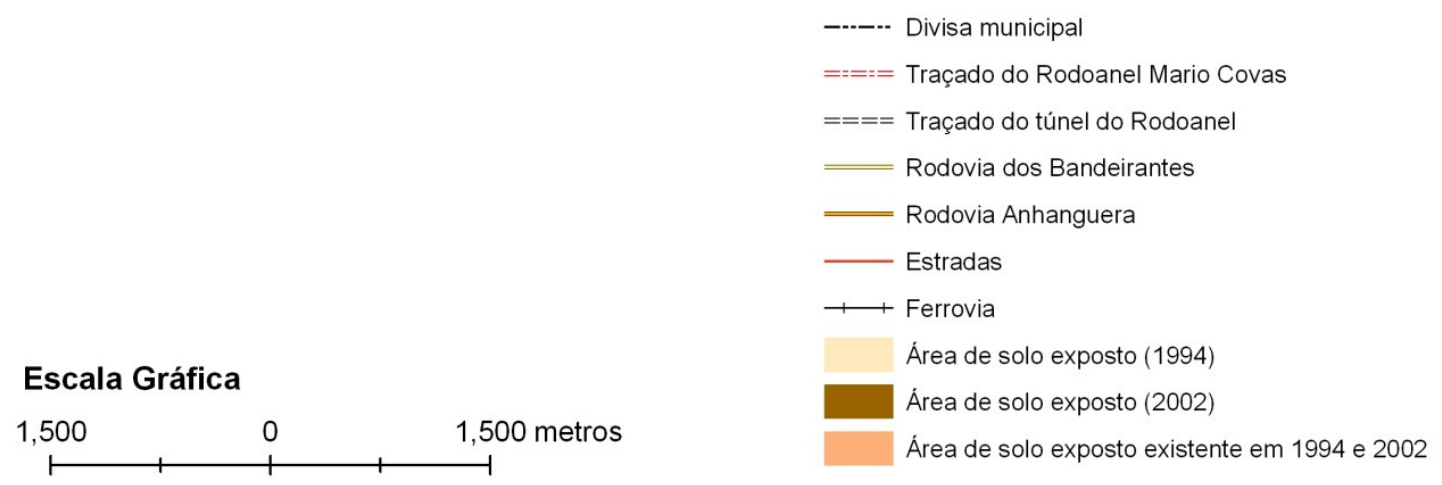

Figura 12: Presença de gramíneas e árvores esparsas em 1994 e 2002.

Elaborado por Larissa L. Volpe, 2009. 


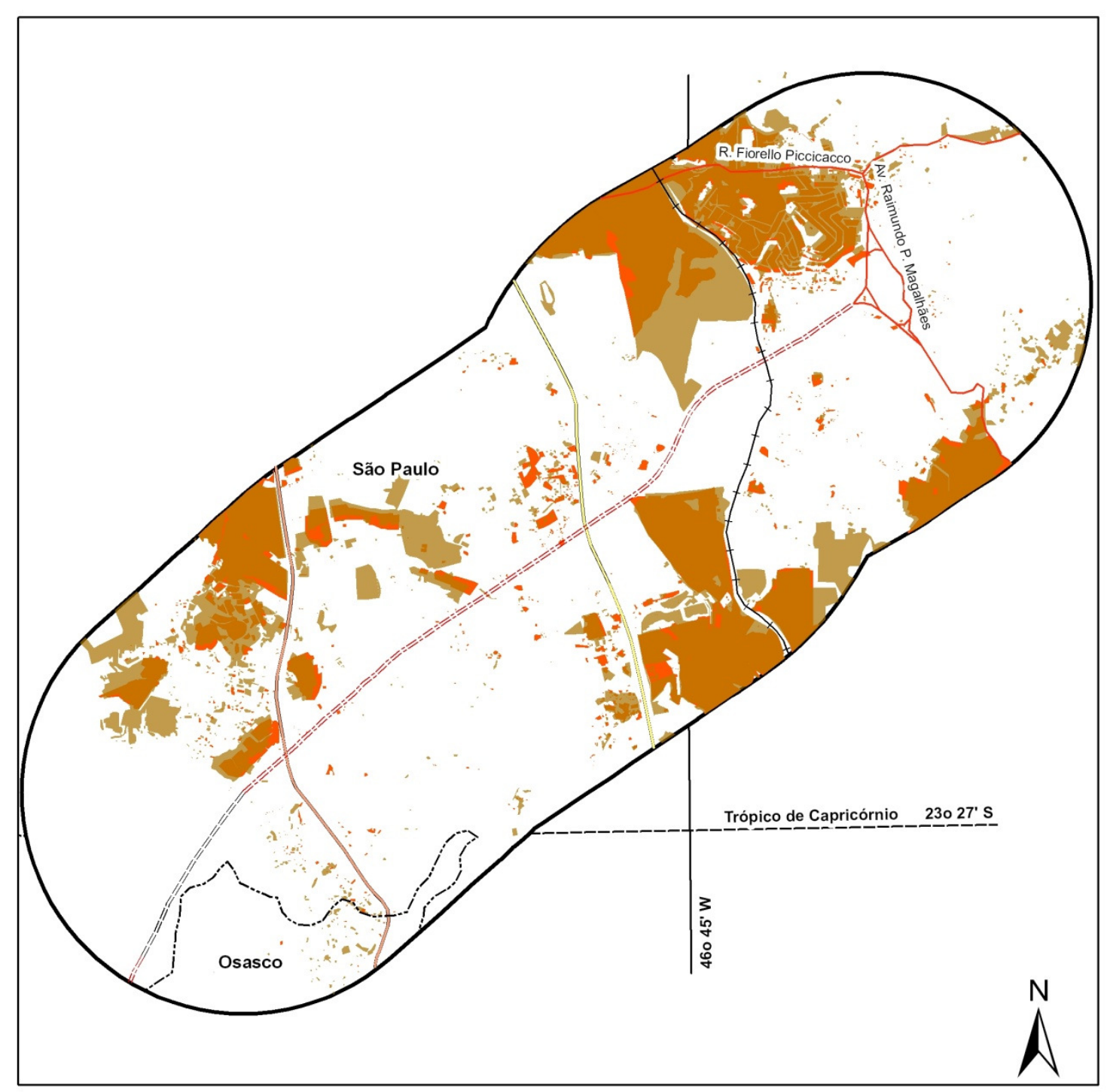

\section{Legenda}

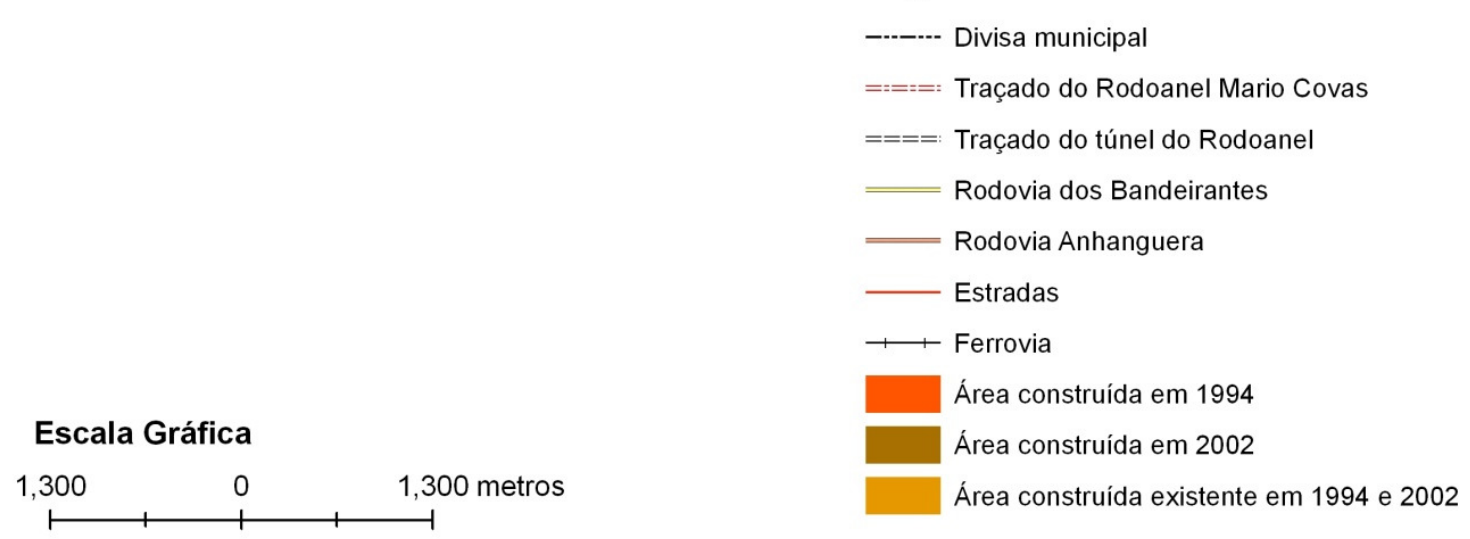

Figura 13: Presença de área construída em 1994 e 2002.

Elaborado por Larissa L. Volpe, 2009. 
Na análise temporal, resultante da classificação analógica em uma área de estudo de 41.787.861 m2, foram levantadas as seguintes informações: A área verde densa cobria cerca de $47,30 \%$ da área de estudo em 1994 e passou a cobrir cerca de 50\% no ano de 2002. Este aumento de área verde densa deve-se a baixa nitidez das fotografias aéreas de 1994. Sobretudo, nota-se que, em alguns trechos onde havia vegetação rasteira no ano de 1994, foi verificado o real aumento de árvores e vegetação mais alta em 2002. Devido a fatores como estes, foi registrado um aumento no que aqui denomina-se áreas verdes densas; $\mathrm{A}$ área de gramínea e árvores esparsas ocupava cerca de $28,80 \%$ da área no ano de 1994, diminuiu para 17,30\% no ano de 2002. A área de gramínea e árvores esparsas foi ocupada, na maioria das vezes, por construções residenciais; A área de solo exposto ocupava cerca de 10,40\% da área no ano de 1994, diminuindo para 9,40\% em 2002. A diminuição da área de solo exposto deve-se à ocupação residencial como a expansão de vilas residenciais e também casos de readequação ambiental como o ocorrido em parte do aterro sanitário de Perus; A área construída ocupava cerca de 13,90\% da área no ano de 1994, aumentando para $20 \%$ em 2002. Pode-se citar como exemplo, a Vila Nova no bairro de Perus que se expandiu sobre a área de gramínea e em direção ao Rodoanel, formando outra ocupação, o Recanto dos Humildes. Segundo entrevistas com moradores e análise das imagens aéreas, após a construção do Rodoanel, esta vila teve ainda uma segunda fase de expansão, em suas margens, formando uma favela (Recanto da Paz), com acessos para pedestres a rodovia.

\section{RESULTADOS E DISCUSSÕES}

Analisando-se os resultados das duas classificações (analógica e automática), pode-se dizer que a classificação automática atende bem aos objetivos de quantificação, sendo a mais adequada a classificação automática por regiões supervisionada (Battacharya com limiar de aceitação de 75\%) das opções testadas na imagem de alta resolução IKONOS.

Na classificação automática supervisionada feita na imagem do ano de 2002, a área verde densa apresentou forte diminuição na classificação automática em relação à analógica. Isto ocorreu porque o método analógico agrupou as áreas verdes com suas sombras na maior parte das vezes, pois não é possível o olho do observador detectar todos os pequenos detalhes, considerar regiões muitas vezes imperceptíveis a olho nu na imagem. Já o método 
automático detecta tais regiões com mais facilidade, distinguindo áreas que parecem ser iguais na interpretação visual. As classificações (analógica e automática) das áreas de gramínea e árvores esparsas apresentaram resultados mais próximos entre si na análise da imagem de 2002. Isto ocorreu porque são áreas mais fáceis do observador interpretar visualmente, pois não possuem tonalidades que provoquem muita confusão como o caso das áreas verdes densas. A área de solo exposto apresentou uma diferença maior nos resultados das duas classificações na imagem de 2002. Isto ocorreu devido ao reconhecimento pela classificação automática de pequenas áreas como terrenos e ruas não asfaltadas nas vilas. Na classificação analógica, muitas vezes, não é possível a separação de pequenas regiões das demais como, por exemplo, pequenas ruas atravessando conjunto denso de casas. Do ano de 1994 para o ano de 2002, a área de solo exposto diminuiu nos resultados da classificação analógica; e em relação à classificação automática esta área aumentou. Isso ocorreu porque, como foi dito acima, o método analógico realizado nas fotografias aéreas de 1994 não foram consideradas ruas e pequenas áreas de solo exposto, pois normalmente, neste método, estas pequenas áreas confundem-se com a classe "área construída".

A classificação analógica da "área construída" na imagem de 2002 apresentou um resultado maior que a classificação automática, pois no método analógico, a interpretação visual considera pequenas regiões de solo exposto parte das vilas por apresentarem confusão, principalmente com telhados de tonalidade clara. Se estas áreas ficam inseridas junto às áreas construídas, logo esta área aumenta. Já na classificação automática, pequenas regiões de solo expostos são consideradas outra classe, diminuindo assim, a área construída.

Estas comparações foram possíveis porque os SIGs mostraram-se capazes de realizar levantamentos quantitativos que auxiliam diretamente no estudo do uso da terra, a partir de conhecimentos prévios, complementando as análises qualitativas. Foi possível a organização e o gerenciamento de informações por meio de banco de dados que possui o diferencial de organizar e gerenciar dados georreferenciados, e também possibilitou uma visualização das informações de fácil compreensão. 


\section{REFERÊNCIAS BIBLIOGRÁFICAS}

BRASIL. Instituto Brasileiro de Geografia e Estatística. (2004) Atlas Geográfico. 2 ed. Rio de Janeiro, IBGE. 204 p.

HO, W. H.; LEE, G. H. Study on Land Use Management with Geographic Information $\begin{array}{llll}\text { Systems. } 2000 . & \text { Disponível }\end{array}$ <http:///www.gisdevelopment.net/aars/arcs/2000/ps2/ps205.pdf.htm>. Acesso em: 18 jun 2007.

LUCHIARI, A.; KAWAKUBO, F. S.; MORATO, R. G. Aplicações do sensoriamento remoto na geografia. In: VENTURI, L. A. B. (Org.). Praticando geografia: técnicas de campo e laboratório. São Paulo, Oficina de textos, 2005, p. 33-54.

PINHO, C. M. D. de. Análise orientada a objetos de imagens de satélite de alta resolução espacial aplicada à classificação de cobertura do solo no espaço intra-urbano: o caso de São José dos Campos - SP. Dissertação (Mestrado em Sensoriamento Remoto) - Instituto Nacional de Pesquisas Espaciais, São José dos Campos, 2006.

SANTOS, M. A Natureza do Espaço: técnica e tempo, razão e emoção. 3. ed. São Paulo, Hucitec, 1999, 308 p.

SANTOS, R. F. dos. Planejamento Ambiental: teoria e prática. São Paulo, Oficina de Textos, 2004. SÃO PAULO (Estado). Desenvolvimento Rodoviário SA. Avaliação Ambiental Estratégica: transporte para o desenvolvimento sustentável. DERSA: São Paulo, 2004.

. Desenvolvimento Rodoviário SA. O rodoanel e a ocupação urbana em seu entorno. DERSA: São Paulo, 2005. 
. Empresa Paulista de Planejamento Metropolitano SA. Metrópoles em dados:

Região Metropolitana de São Paulo. EMPLASA: São Paulo, 2007. Disponível em <http://www.emplasa.sp.gov.br/>. Acesso em 13 mar 2007.

TUTORIAL SPRING. Introdução ao Spring. São José dos Campos, 2002. Disponível em: http://www.dpi.inpe.br/spring/portugues/download.php. Acesso em 20 jun 2004. 